\title{
A PROVA TESTEMUNHAL NO PROCESSO PENAL: ANÁLISE DAS FALSAS MEMÓRIAS NO ESTUPRO DE VULNERÁVEL*
}

\author{
Gabriela Magnus Otto** \\ Felipe Lazzari da Silveira***
}

\section{RESUMO}

0 processo penal, como instrumento fundamental para a aplicação do direito penal material e dimensionamento da pena, tem seus preceitos calcados na aplicação de um sistema acusatório, com plena observância dos direitos das partes. Todavia, a realidade é que o processo penal pende mais para a utilização de um sistema inquisitório, e é através do modo de gestão da prova utilizado pelo julgador que se definirá a sistemática utilizada. 0 modelo de valoração das provas no processo penal brasileiro (livre convencimento motivado) é posto em questão, no presente trabalho, naqueles casos em que o processo dispõe apenas de prova testemunhal para apreciação do julgador. A fragilidade da memória, além da questão biológica temporal, será analisada sob o prisma da incidência do fenômeno das falsas memórias, em especial, e no seu maior campo de ocorrência, no caso do depoimento da criança vítima de estupro de vulnerável. Na busca por meios que controlem os prejuízos para o processo advindos de um depoimento danoso, que reforcem a segurança jurídica dos julgamentos,

* Artigo apresentado ao Curso de Bacharelado em Direito do Centro Universitário Metodista - IPA, como requisito parcial para obtenção do Grau de Bacharel em Direito.

** Graduanda do Curso de Bacharelado em Direito do Centro Universitário Metodista - IPA.

*** Orientador do artigo, Mestre em Ciências Criminais pela PUC/RS e professor do Curso de Bacharelado em Direito do Centro Universitário Metodista - IPA. 
buscamos conhecer o projeto Depoimento Sem Dano que visa justamente a proteção dos infantes no âmbito judicial, bem como a redução de relatos inverídicos.

Palavras-chave: Processo Penal Democrático. Prova Testemunhal. Falsas Memórias. Depoimento sem Dano.

\section{TESTIMONIAL EVIDENCE IN CRIMINAL PROCEDURE: ANALYSIS OF FALSE MEMORIES IN CHILD RAPE}

\section{ABSTRACT}

Criminal procedure, as fundamental instrument to the application of the substantive criminal law and sentencing has its precepts based on the application of an accusatory system with optimal compliance of the parties' rights. Nevertheless, the truth is that the prosecution leans to the use of an inquisitorial system, and it is through the method of proof management used by the judge that the applied scheme will be defined. The model of proof valuation in Brazilian criminal procedure (free motivated persuasion) is called into question in those cases in which the process has only testimonial proof to the judge`s evaluation. The fragility of memory, besides the biological temporal issue, will be analyzed under the prism of the incidence of the phenomenon of false memories, in particular, and in its major domain of occurrence, in the case of testimony of the children victim of rape. In the pursuit of means that control the damages to the prosecution resulting of a harmful testimony, that reinforce the legal security of judgments, we pursued to get to know the project "Testimony Without Damage" that targets exactly the protection of children in legal scope, just as the reduction of untrue reports.

Keywords: Democratic Criminal Prosecution. Testimonial Proof. False Memories. Testimony Without Damage.

\section{INTRODUÇÃO}

No capítulo inicial, tomaremos conhecimento acerca da funcionalidade e instrumentalidade do processo penal como meio utilizado pelo Estado para exercer o direito de punir e também assegurar os direitos dos cidadãos com aplicação do direito penal material, através do Poder Judiciário, com base nos preceitos constitucionais da República Federativa do Brasil, utilizando como balizadores o princípio do devido processo legal (artigo 5으, LIV, 
da Constituição Federal) e o princípio de competência do juiz natural (artigo 5ํㅜ LIII, da Constituição Federal).

Serão delineados os sistemas processuais existentes, quais sejam modelo acusatório e modelo inquisitório, e ainda analisaremos, sob a ótica do entendimento de Aury Lopes Jr., o sistema adotado pelo atual ordenamento processual penal no Brasil. Do qual se extrairá que o elemento determinante deste será o modo de gestão da prova utilizado pelo juiz.

Sob a análise da importância do ato de provar no curso de um processo penal, o segundo capítulo tratará de analisar a prova, em espécie a testemunhal, a qual apresenta-se no ordenamento como o principal meio, e o mais recorrente, utilizado pelas partes para consubstanciar suas alegações.

Ante a preponderância de tal meio probatório, é retratada também sua confiabilidade, tendo em vista que a testemunha narrará os fatos do modo que lhe convir, do modo em que percebeu particularmente os fatos e, ainda do modo em que sua memória guardou os fatos. 0 que põe em xeque sua veracidade, e leva ao julgador a incumbência de valorar o depoimento prestado. Deste modo, fez-se necessário compreender o histórico dos sistemas de valoração da prova (sistema tarifado e íntima convicção) para, principalmente, entender àquele adotado pelo Código Processual Penal e utilizado pelos julgadores, qual seja o livre convencimento motivado.

Os alarmantes números de violência contra crianças e adolescentes, como uma problemática mundial, apresenta ao judiciário um grande número de testemunhos infantis que, recorrentemente, é o único elemento probatório do processo. 0 que, por consequência, acarreta uma maior dificuldade ao julgador no momento de valorar a prova, tendo em vista que os infantes têm maior propensão a produzirem memórias distorcidas.

Será sob a égide do delito de estupro de vulnerável, que analisaremos o papel da testemunha criança, e os aspectos bio- 
lógicos, e principalmente psicológicos que podem, e tendem, a afetar suas memórias.

O capítulo terceiro terá como cerne o estudo do fenômeno das Falsas Memórias, o que assemelha-se muito com uma mentira criada pelo próprio depoente, porém difere desta ao passo em que a pessoa crê honestamente que ocorreu consigo o fato que tem gravado em sua memória, não sendo uma manipulação voluntária da verdade. Fenômeno que acaba incidindo frequentemente na memória de crianças vítima de estupro, ante sua fragilidade e incompleta formação psíquica, e ainda por conta dos abalos sofridos por decorrência da violência sofrida, que podem ser afetados por uma sugestão externa ou pelo efeito de uma informação incorreta.

No entanto, existem métodos utilizados na entrevista da criança que visam à redução de danos nas informações trazidas e ainda evitam o sofrimento do ato de rememorar uma circunstância violenta. Nesta senda, estudaremos o projeto "Depoimento Sem Dano", criado pelo magistrado José Antônio Daltoé Cezar, que visa suprir exatamente estes pontos no depoimento.

\section{PROCESSO PENAL E SUA INSTRUMENTALIDADE}

No capítulo exordial, será feita análise sobre a importância da instrução probatória no processo penal, sob a perspectiva da instrumentalidade do processo, para melhor compreender a importância e necessidade do procedimento para chegar-se à efetiva punição do delinquente.

Tendo em vista que na esfera penal as previsões delitivas e punitivas decorrem de ações violentas que constituem perigo direto à sociedade, gera-se ao Estado - responsável pela garantia de proteção à comunidade e também aos réus - o direito de punir (jus puniendi), pois trata-se de dano causado ao bem comum ${ }^{1}$.

MIRABETE, Julio Fabbrini. Processo Penal. 17 ed. São Paulo: Atlas, 2005. p. 26. 
Deste modo, o Estado define abstratamente fatos que constituem infração penal e prevê determinadas sanções para cada tipo, visando regular o próprio jus puniendi $i^{2}$. 0 qual se transforma de direito em dever a partir do momento que há o cometimento de um crime tipificado, o qual "desce do plano abstrato para o concreto, pois, já agora, o Estado tem o dever de infligir a pena ao autor da conduta proibida"."

A Constituição Federal de 1988 afastou a possibilidade de que conflitos advindos de atos puníveis sejam dirimidos com uso de força e autodefesa e nem mesmo por convenção e autocomposição das partes. Por este motivo, tendo em vista que o Estado detém o direito-poder de punir os que infringem a lei, pois os atos de violência atingem o interesse público, conclui-se que este poder deverá valer-se de um processo penal para ser exercido ${ }^{4}$.

Desta forma, o Estado toma para si a responsabilidade por garantir a observância da lei, delegando ao Poder Judiciário a competência para ver-se ocorrer o devido processo legal, uma vez que previstos na Constituição Federal os princípios que ordenam a atuação dos órgãos jurisdicionais, em seu artigo 5o, LIII e LIV, Constituição Federal ${ }^{5,6 .}$

2 MIRABETE, Julio Fabbrini. Processo Penal. 17 ed. São Paulo: Atlas, 2005. p. 26.

3 TOURINHO FILHO, Fernando da Costa. Processo penal. 26 ed. São Paulo: Saraiva, 2004. p. 10.

4 MIRABETE, Julio Fabbrini. Processo Penal. 17 ed. São Paulo: Atlas, 2005. p. 26 e 27.

5 Art. 5ำ Todos são iguais perante a lei, sem distinção de qualquer natureza, garantindo-se aos brasileiros e aos estrangeiros residentes no País a inviolabilidade do direito à vida, à liberdade, à igualdade, à segurança e à propriedade, nos termos seguintes: (...)

LIII - ninguém será processado nem sentenciado senão pela autoridade competente;

LIV - ninguém será privado da liberdade ou de seus bens sem o devido processo legal; In: BRASIL. Constituição Federal de 1988. Disponível em: < http://www.planalto.gov.br/ccivil_03/constituicao/constituicaocompilado. htm>. Acesso em: 08 nov. 2018.

6 MIRABETE, Julio Fabbrini. Processo Penal. 17 ed. São Paulo: Atlas, 2005. p. 29. 
Do artigo 5ํ, LIV, da Constituição Federal, extrai-se o principal dispositivo sobre a imprescindibilidade do processo, onde previsto o princípio do devido processo legal, com a garantia de que antes de ver privada a sua liberdade, todo cidadão terá direito ao processo legal.

Acerca deste princípio, Nestor Távora refere em sua obra Curso de Direito Processual Penal:

Com isto, consagra-se a necessidade do processo tipificado, sem a supressão e/ou desvirtuamento de atos essenciais. Em se tratando de aplicação da sanção penal, é necessário que a reprimenda pretendida seja submetida ao crivo do Poder Judiciário, pois nulla poena sine judicio. Mas não é só. A pretensão punitiva deve perfazer-se dentro de um procedimento regular, perante a autoridade competente, tendo por alicerce provas validamente colhidas, respeitando-se o contraditório e a ampla defesa. ${ }^{7}$

O Princípio do juiz natural, previsto no artigo 5ํㅡ, LIII, da Constituição Federal, reflete a delegação do Poder Estatal ao Judiciário, como leciona Mirabete ${ }^{8}$. 0 dispositivo prevê o direito de que todo cidadão será processado e sentenciado tão somente pela autoridade competente, qual seja o Juiz de Direito, que é o juiz natural para julgamento de ações delituosas. Destaca-se que a Constituição não trata de Juízo competente (matéria tratada no Código de Processo Penal) e sim de autoridade competente, aquele constitucionalmente competente para processar e julgar ${ }^{9}$.

7 ALENCAR, Rosmar Rodrigues; TÁVORA, Nestor. Curso de direito processual penal. 11 ed. Salvador: JusPODIVM, 2009. Paginação Irregular. Disponível em: <https://forumdeconcursos.com/wp-content/uploads/wpforo/attachments/4032/184-Curso-de-Direito-Processual-Penal-Nestor-Tvora-e-Rosmar-Rodrigues-Alencar-2016.pdf $>$.

8 MIRABETE, Julio Fabbrini. Processo Penal. 17 ed. São Paulo: Atlas, 2005. p. 51.

9 CAPEZ, Fernando. Curso de processo penal. 23 ed. São Paulo: Saraiva, 2016. Paginação Irregular. Disponível em: <http://assindelp.org.br/files/conteudo_arquivo/12005/fernando-capez---curso-de-processo-penal---2016.pdf>. 
Percebe-se que na nossa legislação maior, é instituído o processo como indispensável à aplicação de sanções, por este motivo, no direito penal, o processo é o instrumento fundamental para aplicação do direito material. Uma vez que prescinde processo para aplicação de uma pena, a qual será formulada pelo ente competente, qual seja o juiz, conforme reza Aury Lopes Jr., em sua obra Direito Processual Penal e sua Conformidade Constitucional acerca do tema:

Impõe-se a necessária utilização da estrutura preestabelecida pelo Estado - o processo penal - em que, mediante atuação de um terceiro imparcial, cuja designação não corresponde à vontade das partes e resulta da imposição da estrutura institucional, será apurada a existência do delito e sancionado o autor. ${ }^{10}$

0 processo penal é o meio utilizado para perfectibilizar o direito material penal. ${ }^{11}$ É o instrumento utilizado pelo Estado responsável por promover a proteção da comunidade e também dos réus - instituído como o meio necessário para chegar-se à pena do delito imputado ${ }^{12}$.

Lopes Jr. analisa a necessidade do devido processo penal em relação à pena, referindo que há relação direta e imprescindível entre o delito, o processo e a pena, ao passo que se existe delito, existe a necessidade de pena, a qual prescinde de processo para mensurá-la $\mathrm{a}^{13}$.

10 LOPES JR, Aury. Direito processual penal. 9 ed. São Paulo: Saraiva, 2012. p. 85.

11 ALVES, Leonardo Barreto Moreira. Processo Penal: parte geral. 8 ed. Bahia: JusPODIVM, 2018. p. 30. Disponível em: <https://forumdeconcursos.com/ wp-content/uploads/wpforo/attachments/2/1948-Coleo-Sinopses-paraConcursos-Processo-Penal-V7-2018-Leonardo-Barreto-Moreira-Alves.pdf $>$.

12 LOPES JR, Aury. Introdução crítica ao processo penal: fundamentos da instrumentalidade garantista. 3 ed. Rio de Janeiro: Lumen Juris, 2005. p. 3.

13 LOPES JR, Aury. Direito processual penal. 9 ed. São Paulo: Saraiva, 2012. p. 86. 
A instrumentalidade necessária do processo penal exsurge na medida em que ele não é dispensado sob nenhuma hipótese, ao passo que se há um delito praticado e surge a possibilidade de aplicar sanção, por força legal, instituir-se-á processo. Não sendo eximido nem mesmo se vier ao conhecimento a confissão por parte de quem o praticou ou ainda seu consentimento em ser submetido à pena ${ }^{14}$.

Nesta senda, é perceptível que o processo penal assegura as garantias constitucionais, não apenas para impor necessariamente a aplicação de punição, mas também para garantir direitos constitucionais do acusado, tal como o contraditório e a ampla defesa, e até mesmo proteger o direito soberano da dignidade da pessoa humana ${ }^{15}$.

Acerca da instrumentalidade constitucional do processo penal discorre Geraldo Prado em sua obra Sistema Acusatório, fazendo menção à Eusebio Fernandez:

O desenvolvimento do paradigma da modernidade radicou-se no ideal democrático, de modo que nada é mais natural que o relevo dado à Constituição entre as demais leis, decorrente do convencimento de que aquela assegura a divisão dos poderes do Estado, mediante sistema de freios e contrapesos, bem como tutela os direitos fundamentais, conformando toda ordem jurídica ${ }^{16}$.

Deste modo, o processo penal é visto sob o prisma de um instrumento de efetivação da democracia, o qual dá poderes ao

14 LOPES JR, Aury. Direito processual penal. 9 ed. São Paulo: Saraiva, 2012. p. 88.

15 LOPES JR, Aury. Direito processual penal. 9 ed. São Paulo: Saraiva, 2012. p. 90-91.

16 FERNANDEZ, Eusebio. Teoria de La Justicia y Derechos Humanos. Madrid: Debates, 1991. p. 77. apud PRADO, Geraldo. Sistema Acusatório: A Conformidade Constitucional das Leis Processuais Penais. Rio de Janeiro: Lumen Juris, 2005. Paginação Irregular. Disponível em: < http://professor. pucgoias.edu.br/SiteDocente/admin/arquivosUpload/7782/material/ Livro\%20-Sistema\%20Acusatorio\%20-\%20Geraldo\%20Prado.pdf>. 
Estado na medida em que também garante os direitos individuais do acusado ${ }^{17}$.

Cumpre referir, em breve apontamento, que a democracia é um atributo do próprio Estado que garante igualdade e liberdade aos cidadãos ${ }^{18}$, e que como reflexo percebemos que o processo penal é o próprio instrumento para garantia de direitos e também garantia contra o arbítrio do Estado ${ }^{19}$.

0 caráter democrático do processo penal faz com que este seja guiado de acordo com os princípios da Constituição Federal, a qual nos encaminha para um processo garantista dotado de diversas proteções ao indivíduo ${ }^{20}$.

Acerca deste caráter, refere Luiz Gabriel Batista Neves ${ }^{21}$ :

O Estado Democrático de Direito tem como peculiaridade a elaboração de uma ordem jurídica piramidal, em que a Constituição serve para dar validade às demais normas do sistema. Noutros termos, o sistema processual penal que deverá prevalecer será aquele que esteja de acordo com os mecanismos de proteção da Democracia e, especialmente, da Carta Magna.

17 PRADO, Geraldo. Sistema acusatório. A conformidade constitucional das leis processuais penais. 3 ed. Rio de Janeiro: Lumen Juris, 2005. Paginação Irregular. Disponível em: <http://professor.pucgoias.edu.br/SiteDocente/ admin/arquivosUpload/7782/material/Livro\%20-Sistema\%20Acusatorio\%20-\%20Geraldo\%20Prado.pdf>.

18 DOS REIS, Helena Esser. A Democracia Como Processo: política e educação no pensamento de Tocqueville. [s.l.]: Revista Contexto \& Educação, 2009. v. 24, p. 99.

19 MOREIRA, Rômulo de Andrade. O Processo Penal como Instrumento de Democracia. [s.l.]: JUS, abr. 2004. Paginação irregular. Acesso em: <https:// jus.com.br/artigos/5224/o-processo-penal-como-instrumento-de-democracia>.

20 FISCHER, Douglas. 0 Sistema acusatório brasileiro à luz da Constituição Federal de 1988 e o PL 156. Salvador: JusPodivm, 2012. p. 4. Disponível em: <http://www.prrj.mpf.mp.br/custoslegis/revista_2011/2011_Dir_Penal_fischer.pdf $>$.

21 BATISTA NEVES, Luiz Gabriel. A Função do Processo Penal no Estado Democrático de Direito. Salvador: UNIFACS, 2014. p. 2 Disponível em: <www.revistas.unifacs.br/index.php/redu/article/download/2923/2115>. 
Ao analisarmos a instrumentalidade processual, importante classificarmos os sistemas que norteiam este procedimento, os quais dividem-se em acusatório e inquisitório, diferindo um do outro no que tange a maior liberdade individual no primeiro, e a maior repressão no último 22 .

O sistema acusatório é o reflexo de um moderno sistema de processo, uma vez que tem seus preceitos guardados na divisão definida entre acusação e defesa, tendo o juiz como figura equidistante e imparcial, perfazendo apenas a figura garantidora dos direitos das partes, sem interferências processuais ${ }^{23}$.

Este sistema, que nasceu no Direito Romano e Grego, inicialmente tinha como preceito a oralidade e a publicidade de seus atos, que se perfazia muitas vezes através de algum cidadão que assumia o papel de acusar um crime, e eram submetidos à órgãos (juízes) não pertencentes ao Estado. A situação de se pôr nesta posição, era, por muitas vezes, utilizada como método de exposição para declamar em público e alcançar ambições políticas ${ }^{24}$.

A principal característica do modelo acusatório era de que o processo se perfizesse sempre pelo actum trium personarum (ato de três sujeitos), bem divididos e determinados, quais sejam: acusação, defesa e julgador. Havendo perfeita igualdade entre a defesa e a acusação e um órgão julgador imparcial ${ }^{25}$.

22 LOPES JR., Aury. Introdução crítica ao processo penal: fundamentos da instrumentalidade garantista. 3 ed. Rio de Janeiro: Lumen Juris, 2005. p. 156.

23 LIMA, Renato Brasileiro de. Manual de processo penal. 4 ed. Salvador: JusPodivm, 2014. Paginação Irregular. Disponível em: < https://forumdeconcursos. com/wp-content/uploads/wpforo/attachments/4032/174-Manual-de-Processo-Penal-Renato-Brasileiro-de-Lima-2016-Volume-Unico-4-Ed.pdf>.

24 LOPES JR., Aury. Introdução crítica ao processo penal: fundamentos da instrumentalidade garantista. 3 ed. Rio de Janeiro: Lumen Juris, 2005. p. 157.

25 MIRABETE, Julio Fabbrini. Processo Penal. 17 ed. São Paulo: Atlas, 2005. p. 43. 
O sistema possuía algumas particularidades, além das já explanadas, vejamos algumas ${ }^{26}$ :

- Era vedada a denúncia anônima;

- Constituía crime a falsa denúncia de delito;

- A acusação se reportava por escrito e indicava provas;

- Contraditório e direito de defesa amplos;

- Julgamentos orais e públicos.

Já, desde o princípio, a principal crítica feita ao sistema era o fato de o julgador se manter adstrito às provas apresentadas pelas partes, sendo que muitas vezes apresentavam-se deficitárias, e ainda assim o Juiz deveria decidir com base somente no que lhe era apresentado ${ }^{27}$. E foi a partir do século XIII que este sistema começou a entrar em declínio, dando espaço a um novo modelo ${ }^{28}$, o qual analisaremos a seguir.

O Sistema Inquisitório surge por volta do século XIII, mudando o cenário do processo penal radicalmente, ao apresentar um sistema totalmente oposto ao sistema acusatório. Desconstruindo a organização perfeitamente dividida em acusação, defesa e julgador inerte ${ }^{29}$.

26 LOPES JR, Aury. Introdução crítica ao processo penal: fundamentos da instrumentalidade garantista. 3 ed. Rio de Janeiro: Lumen Juris, 2005. p. 158.

27 LOPES JR, Aury. Introdução crítica ao processo penal: fundamentos da instrumentalidade garantista. 3 ed. Rio de Janeiro: Lumen Juris, 2005. p. 159.

28 LIMA, Renato Brasileiro de. Manual de processo penal. 4 ed. Salvador: JusPodivm, 2014. Paginação Irregular. Disponível em: < https://forumdeconcursos. com/wp-content/uploads/wpforo/attachments/4032/174-Manual-de-Processo-Penal-Renato-Brasileiro-de-Lima-2016-Volume-Unico-4-Ed.pdf>.

29 LIMA, Renato Brasileiro de. Manual de processo penal. 4 ed. Salvador: JusPodivm, 2014. Paginação Irregular. Disponível em: < https://forumdeconcursos. com/wp-content/uploads/wpforo/attachments/4032/174-Manual-de-Processo-Penal-Renato-Brasileiro-de-Lima-2016-Volume-Unico-4-Ed.pdf>. 
As mudanças para um novo sistema surgem a partir da necessidade de uma produção probatória mais robusta e completa. Na medida em que no sistema acusatório, por vezes, as partes não construíam embasamento probatório suficiente para a construção da decisão judicial. Deste modo afetando a efetividade do combate à delinquência, e levando a crer que o Estado deveria assumir este papel para a efetivação da devida legalidade ${ }^{30}$.

No entanto, o processo se torna "mais uma forma autodefensiva de administração da justiça do que um genuíno processo da verdade ${ }^{31 "}$. A igualdade e liberdade não eram mais parte da composição principiológica que conduz o processo, e o que era um duelo leal e franco entre as partes, agora torna-se uma relação desigual entre um juiz acusador e o acusado que não tem garantia alguma ${ }^{32}$.

A figura do juiz neste sistema é marcada por um caráter de investigador, acusador e julgador, através de um processo escrito e secreto, onde tornou-se permitida a prática de denúncias anônimas, inclusive, o depoimento das testemunhas eram de forma totalmente sigilosa para que o réu não tomasse conhecimento ${ }^{33}$.

No sistema inquisitório a confissão era a prova mais forte que poderia ser produzida e era em busca dela que o processo tramitava. A confissão era o cerne do processo, e o juiz, que trabalhava em busca desta, detinha poderes inclusive para torturar o acusado para que confessasse a autoria do delito ${ }^{34}$.

A tortura era vista como uma "técnica especial" para alcançar a verdade. Havia tipos progressivos de tortura e a prática era

30 LOPES JR, Aury. Introdução crítica ao processo penal: fundamentos da instrumentalidade garantista. 3 ed. Rio de Janeiro: Lumen Juris, 2005. p. 159.

31 MIRABETE, Julio Fabbrini. Processo Penal. 17 ed. São Paulo: Atlas, 2005. p. 43.

32 LOPES JR, Aury. Introdução crítica ao processo penal: fundamentos da instrumentalidade garantista. 3 ed. Rio de Janeiro: Lumen Juris, 2005. p. 162.

33 LOPES JR., Aury. Introdução crítica ao processo penal: fundamentos da instrumentalidade garantista. 3 ed. Rio de Janeiro: Lumen Juris, 2005. p. 165.

34 LOPES JR, Aury. Introdução crítica ao processo penal: fundamentos da instrumentalidade garantista. 3 ed. Rio de Janeiro: Lumen Juris, 2005. p. 166. 
permitida apenas uma vez por dia, durante o prazo de 15 dias. Expirando este prazo sem que tenha havido a confissão pelo acusado, este era liberado ${ }^{35}$.

A defesa era de toda inútil ao processo, pois se o acusado confessasse, não havia a necessidade de constituição de advogado, ademais este tinha o papel de fazer com que o suspeito realizasse a confissão tão logo, para que a pena fosse aplicada e a execução começasse de imediato ${ }^{36}$.

Deste modo, o sistema ficou marcado pela extinção da separação de funções das partes. A ampla defesa e o contraditório foram extintos, dando espaço apenas para a atuação do juiz-inquisidor que detinha os poderes de acusar e provar, em ambas as fases do processo, e ainda julgar. Comprometendo plenamente o princípio da imparcialidade do juiz, transformando o acusado em um mero objeto no processo, isento de direitos ${ }^{37}$.

0 radical sistema inquisitório fracassou, dando espaço novamente à adoção de medidas provindas de um sistema acusatório, porém, desta vez o poder de acusar foi incumbido ao Estado, mas não mais concentrado na pessoa do Juiz (este agora faria o papel apenas de julgar) e nem mesmo nas mãos de cidadãos. Cria-se neste momento o papel do Ministério Público, órgão responsável por realizar a acusação na fase processual ${ }^{38}$.

35 LOPES JR., Aury. Introdução crítica ao processo penal: fundamentos da instrumentalidade garantista. 3 ed. Rio de Janeiro: Lumen Juris, 2005. p. 167.

36 LOPES JR, Aury. Introdução crítica ao processo penal: fundamentos da instrumentalidade garantista. 3 ed. Rio de Janeiro: Lumen Juris, 2005. p. 166.

37 LIMA, Renato Brasileiro de. Manual de processo penal. 4 ed. Salvador: JusPodivm, 2014. Paginação Irregular. Disponível em: < https://forumdeconcursos.com/wp-content/uploads/wpforo/attachments/4032/174-Manualde-Processo-Penal-Renato-Brasileiro-de-Lima-2016-Volume-Unico-4-Ed. $\mathrm{pdf}>$.

38 LOPES JR., Aury. Introdução crítica ao processo penal: fundamentos da instrumentalidade garantista. 3 ed. Rio de Janeiro: Lumen Juris, 2005. p. 168. 
Os sistemas puros deixaram de existir, na medida em que se fundem os princípios de um sistema com os do outro. 0 novo sistema adotado vem caracterizado pela divisão do processo em duas fases: fase pré-processual e fase processual, sendo a primeira de caráter inquisitório e a segunda acusatório. Daí surge a nomeação de "sistema misto". O sistema misto surgiu pela primeira vez no ordenamento jurídico francês, que foi o responsável pela cisão de fase investigatória e processual ${ }^{39}$.

Embora atualmente todos os sistemas processuais sejam intrinsecamente mistos, pois inexiste algum sistema que detenha apenas as características de um só sistema, Aury Lopes Jr, analisa as características do processo penal brasileiro e indica que todas estas pendem em sua essência para um procedimento inquisitório, muito embora as garantias constitucionais do país sugerem uma sistemática acusatória. ${ }^{40}$

0 autor mencionado intitula o sistema bifásico (inquérito policial e ação penal) como uma verdadeira falácia, tendo em vista o fato de o inquérito policial, o qual é plenamente inquisitório e sem nenhuma possibilidade de contraditório, integrar os autos do processo judicial, contemplando o livre acesso do juiz ao corpo probatório colhido de forma inquisitória ${ }^{41}$.

Deste modo, inevitável que as provas colhidas na fase pré-processual influenciem diretamente na decisão do Juiz. E é evidente que esta situação de fato se repete ante as corriqueiras sentenças prolatadas que são embasadas na prova colhida na primeira fase que vem "corroborada" na fase judicial ${ }^{42}$.

39 LOPES JR., Aury. Introdução crítica ao processo penal: fundamentos da instrumentalidade garantista. 3 ed. Rio de Janeiro: Lumen Juris, 2005. p. 169.

40 LOPES JR., Aury. Introdução crítica ao processo penal: fundamentos da instrumentalidade garantista. 3 ed. Rio de Janeiro: Lumen Juris, 2005. p. 168-169.

41 LOPES JR., Aury. Introdução crítica ao processo penal: fundamentos da instrumentalidade garantista. 3 ed. Rio de Janeiro: Lumen Juris, 2005. p. 170.

42 LOPES JR., Aury. Introdução crítica ao processo penal: fundamentos da instrumentalidade garantista. 3 ed. Rio de Janeiro: Lumen Juris, 2005. p. 170. 
No momento em que o inquérito policial é automaticamente juntado ao processo, não há como ter o controle da íntima convicção do juiz prolator acerca de estar o decisum baseado tão somente no conjunto probatório colhido durante a segunda fase ou não. Refere Aury Lopes Jr. acerca: "A eleição (culpado ou inocente) é o ponto nevrálgico do ato decisório e pode ser feita com base nos elementos do inquérito policial e disfarçada com um bom discurso ${ }^{43}$ ".

O caráter acusatório do processo vai se afastando do processo penal brasileiro na medida em que apenas a divisão de funções já não é critério para caracterizá-lo, se não vier acompanhada de outros critérios determinantes, como por exemplo, a gestão da prova ${ }^{44}$.

No processo penal brasileiro o juiz assume indiretamente o papel de acusador por diversas vezes ao utilizar-se de direitos que lhe são outorgados pelo Código de Processo Penal, como por exemplo: ouvir testemunhas além das indicadas, determinar diligência de ofício, determinar prisão preventiva de ofício ${ }^{45}$.

Luis Gabriel Batista Neves, também faz alusão ao tema em seu artigo intitulado "Sistemas Processuais Penais" ao levantar a discussão acerca do poder do Juiz de requisitar instauração de inquérito policial de ação penal pública, conforme prevê o artigo 5ํㅗ II, do Código de Processo Penal ${ }^{46}$, sendo que possivelmente

43 LOPES JR., Aury. Introdução crítica ao processo penal: fundamentos da instrumentalidade garantista. 3 ed. Rio de Janeiro: Lumen Juris, 2005. p. 170.

44 LOPES JR., Aury. Introdução crítica ao processo penal: fundamentos da instrumentalidade garantista. 3 ed. Rio de Janeiro: Lumen Juris, 2005. p. 173.

45 LOPES JR., Aury. Introdução crítica ao processo penal: fundamentos da instrumentalidade garantista. 3 ed. Rio de Janeiro: Lumen Juris, 2005. p. 172.

46 Art. $5^{\circ}$ Nos crimes de ação pública o inquérito policial será iniciado:

II - mediante requisição da autoridade judiciária ou do Ministério Público, ou a requerimento do ofendido ou de quem tiver qualidade para representálo. In: BRASIL. Decreto-lei no 3.689, de 3 de outubro de 1941. Código de Processo Penal. Diário Oficial [da] República Federativa do Brasil. Poder Executivo. Brasília, DF, 1941. Disponível em: < http://www.planalto.gov.br/ ccivil_03/Decreto-Lei/Del3689.htm>. Acesso em: 08 nov. 2018. 
será o Juiz prevento competente para julgar a possível ação penal que gerará (por força do artigo 83, do mesmo Diploma Legal ${ }^{47}$ ). Desta análise, faz a crítica:

[...] É como se o magistrado estivesse dizendo: investigue, após isso envie para o parquet para oferecer a denúncia, que quando estes autos chegarem às minhas mãos, com absoluta certeza, eu vou condenar. E a imparcialidade, joga no lixo? Ou se esqueceram que a Constituição é muito mais do que uma simples folha de papel, que é norma fundamental do Estado, que é suprema, hierárquica e se sobrepõe diante das demais normas? ${ }^{48}$

Da análise dos sistemas processuais, chega-se à conclusão que a espinha dorsal do processo penal é a gestão da prova ${ }^{49}$. E que embora a Constituição Federal seja embasada em princípios totalmente voltados ao sistema acusatório (e inclusive traga expressa a competência exclusiva do Ministério Público em acusar), a doutrina brasileira entende que o processo penal seja calcado em um sistema inquisitório ${ }^{50}$.

47 Art. 83. Verificar-se-á a competência por prevenção toda vez que, concorrendo dois ou mais juízes igualmente competentes ou com jurisdição cumulativa, um deles tiver antecedido aos outros na prática de algum ato do processo ou de medida a este relativa, ainda que anterior ao oferecimento da denúncia ou da queixa.In: BRASIL. Decreto-lei no 3.689, de 3 de outubro de 1941. Código de Processo Penal. Diário Oficial [da] República Federativa do Brasil. Poder Executivo. Brasília, DF, 1941. Disponível em: < http://www.planalto.gov.br/ccivil_03/Decreto-Lei/Del3689.htm>. Acesso em: 08 nov. 2018.

48 BATISTA NEVES, Luiz Gabriel. Sistemas processuais penais. Salvador: UNIFACS, 2014. p. 20. Disponível em: https://revistas.unifacs.br/index. $\mathrm{php} / \mathrm{redu} /$ article/viewFile/2924/2116

49 LOPES JR., Aury. Introdução crítica ao processo penal: fundamentos da instrumentalidade garantista. 3 ed. Rio de Janeiro: Lumen Juris, 2005. p. 173.

50 VOLPATO, Dayana. A gestão da prova como elemento determinante do sistema processual penal. Itajaí: UNIVALI, 2010. p. 53-59. Disponível em: <http://siaibib01.univali.br/pdf/Dayana\%20Volpato.pdf>. 


\section{SISTEMA DE VALORAÇÃO PROBATÓRIA E A PROVA TESTEMUNHAL NO PROCESSO PENAL DEMOCRÁTICO}

A prova judiciária tem como objetivo a reconstrução dos fatos investigados no processo, visando o alcance da maior coincidência com a verdade ocorrida e os fatos históricos apresenta$\operatorname{dos}^{51}$. 0 direito de provar vem garantido por disposições legais, calcadas basicamente no direito à igualdade, ao contraditório, a ampla defesa e o in dubio pro reo ${ }^{52}$.

Para que o juiz exerça sua função jurisdicional imputando responsabilidade e impondo pena, é preciso que as partes o demonstrem e o convençam dos fatos alegados. 0 julgador que buscará compreender a verdade se convencerá quando a versão apresentada encaixar-se perfeitamente com os elementos fáticos e depoimentos trazidos a seu conhecimento durante a instrução do processo. Estas demonstrações são o que constituem a prova. ${ }^{53}$ Deste modo, a definição de provar: "provar é produzir um estado de certeza na consciência e mente do juiz, para sua convicção a respeito da existência ou inexistência de um fato (...)" 54 .

Diante do artigo 155, do Código de Processo Penal ${ }^{55}$, o ato de provar apresenta-se como um ônus processual, consideran-

51 DE OLIVEIRA, Eugênio Pacelli. Curso de processo penal. 18 ed. São Paulo: Atlas, 2014. p. 327.

52 LOPES JR, Aury. Direito processual penal. 9 ed. São Paulo: Saraiva, 2012. p. 545.

53 MIRABETE, Julio Fabbrini. Processo Penal. 17 ed. São Paulo: Atlas, 2005. p. 274.

54 TORNAGHI, Hélio. Curso de Processo Penal. 5 ed. São Paulo: Saraiva, 1988. p. 265. apud MIRABETE, Julio Fabbrini. Processo Penal. 17 ed. São Paulo: Atlas, 2005. p. 274.

55 Art. 155. O juiz formará sua convicção pela livre apreciação da prova produzida em contraditório judicial, não podendo fundamentar sua decisão exclusivamente nos elementos informativos colhidos na investigação, ressalvadas as provas cautelares, não repetíveis e antecipadas. (...) In: BRASIL. Decreto-lei no 3.689, de 3 de outubro de 1941. Código de Processo Penal. Diário Oficial [da] República Federativa do Brasil. Poder Executivo. Brasília, DF, 1941. Disponível em: < http://www.planalto.gov.br/ccivil_03/ Decreto-Lei/Del3689.htm>. Acesso em: 08 nov. 2018. 
do que quem deseja ver reconhecida sua pretensão tem como contrapeso o ônus de provar a veracidade de suas alegações. Porém, vejamos que o ônus não se confunde com obrigação de provar, tendo em vista que o ônus é uma garantia facultativa que não constitui fato em contradição com a ordem judicial se não exercido, ao contrário da obrigação (em que sua inobservância pode inclusive levar à penalização) ${ }^{56}$.

Considerando que as partes provam para produzir benefícios para si mesmas ante a convicção do juiz, o ato de deixar de exercer o ônus probandi causa prejuízo tão somente para si, que deixa de utilizar o meio de obtenção de sua pretensão.

$\mathrm{Na}$ medida em que provar é ônus, também é direito. 0 direito à prova (right to evidence) vem garantido por diversas disposições legais, calcadas basicamente nos direitos e princípios previstos constitucionalmente. Tais como a igualdade, o contraditório e a ampla defesa ${ }^{57}$.

0 direito à prova é direito fundamental no processo penal, e as partes devem apresentar elementos admissíveis, lícitos, válidos e que observem o devido processo legal. Ao juiz incumbe garantir a efetividade do direito à prova, certificando-se que não há qualquer obstáculo que impeça as partes de exercê-lo ${ }^{58}$.

Como o juiz tem a incumbência de prolatar sentença justa baseando-se nos elementos probatórios que lhe foram apresentados, é de sua responsabilidade garantir que os direitos

56 De CAmargo ARAnHA, Adalberto José Q.T. Da Prova No Processo Penal . 5 ed. São Paulo: Saraiva, 1999. p. 8.

57 GIACOMOLLI, Nereu José. 0 devido processo penal: abordagem conforme a Constituição Federal e o Pacto de São José da Costa Rica: cases da Corte Interamericana, do Tribunal Europeu e do STF. São Paulo: Atlas, 2014. p. 159.

58 GIACOMOLLI, Nereu José. 0 devido processo penal: abordagem conforme a Constituição Federal e o Pacto de São José da Costa Rica: cases da Corte Interamericana, do Tribunal Europeu e do STF. São Paulo: Atlas, 2014. p. 161 
constitucionais sejam observados, para que a verdade chegue até ele do modo mais condizente com a realidade possível ${ }^{59}$.

Neste passo, a produção de provas é direito das partes com amparo constitucional no direito à ampla defesa e contraditório, sendo obrigação do Estado - representado pelo Judiciário - fornecer todos os recursos para que as partes às explanem, sem haver cerceamento de defesa ou acusação ${ }^{60}$.

O Processo Penal como instrumento de reconstrução do fato (crime) ocorrido, é o meio pelo qual leva-se ao Juiz o conhecimento de como se deram os fatos imputados ao homem em julgamento (através da explanação de provas). Aury Lopes Jr. aponta este meio como um paradoxo temporal, no qual um juiz julga no presente, um fato ocorrido no passado, com provas colhidas em um passado recente e projetando uma pena para cumprimento futuro ${ }^{61}$.

Deste modo, necessário o processo de recognição do juiz sobre o fato histórico que veio ao seu conhecimento, o qual ocorre por meio do conjunto probatório carreado aos autos. 0 juiz é a parte ignorante do processo, o qual terá de tomar conhecimento tão somente com base em provas colhidas, trabalhando com base em um conhecimento empírico ${ }^{62}$.

As partes tratam de dedicar-se em uma explanação de provas processuais que façam crer o juiz que sua versão é a que inspira maior verdade. Conforme Aury é inquestionável que o juiz elege

59 ARAÚJO. Caroline. 0 Direito à Prova no Processo Penal. In: GIACOMOLLI, Nereu José. VASCONCELLOS, Vinícius Gomes de. (Orgs.) Processo Penal e Garantias Constitucionais. Rio de Janeiro: Lumen Juris, 2014. p.91.

60 LIMA, Renato Brasileiro de. Manual de processo penal. 4 ed. Salvador: JusPodivm, 2014. Paginação Irregular. Disponível em: < https://forumdeconcursos. com/wp-content/uploads/wpforo/attachments/4032/174-Manual-de-Processo-Penal-Renato-Brasileiro-de-Lima-2016-Volume-Unico-4-Ed.pdf>.

61 LOPES JR, Aury. Direito processual penal. 9 ed. São Paulo: Saraiva, 2012. p. 535.

62 LOPES JR, Aury. Direito processual penal. 9 ed. São Paulo: Saraiva, 2012. p. 536. 
a versão dos fatos que mais lhe convence, dando a esta a maior valoração no conjunto probatório, a exarando na sentença ${ }^{63}$.

Deste modo, a atividade probatória toma o lugar de instrumento mais importante do processo penal, na medida em que é a força de seus elementos que norteará o decisum, e será o meio principal do acusado defender-se.

Ao passo que o juiz se tonaria adstrito somente aos elementos probatórios produzidos pelas partes, para que formasse sua convicção para condenar ou absolver um sujeito acusado de cometer um delito, o ordenamento jurídico, extrapolando os princípios do sistema acusatório e utilizando-se de um modelo inquisitório, atribuiu poderes de produção probatória ao julgador em seu artigo 156, I e II, do Código de Processo Penal ${ }^{64}$, tanto na fase investigatória, quanto na processual. ${ }^{65}$

A previsão do artigo vem calcada no mito da busca da "verdade", o que extrapola os paradigmas do modelo processual acusatório, de acordo com a crítica erigida no capítulo anterior, na medida em que se o modelo fosse de fato adotado e seguido,

63 LOPES JR, Aury. Direito processual penal. 9 ed. São Paulo: Saraiva, 2012. p. 538.

64 Art. 156. A prova da alegação incumbirá a quem a fizer, sendo, porém, facultado ao juiz de ofício:

I - ordenar, mesmo antes de iniciada a ação penal, a produção antecipada de provas consideradas urgentes e relevantes, observando a necessidade, adequação e proporcionalidade da medida;

II - determinar, no curso da instrução, ou antes de proferir sentença, a realização de diligências para dirimir dúvida sobre ponto relevante. In: BRASIL. Decreto-lei no 3.689, de 3 de outubro de 1941. Código de Processo Penal. Diário Oficial [da] República Federativa do Brasil. Poder Executivo. Brasília, DF, 1941. Disponível em: < http://www.planalto.gov.br/ccivil_03/ Decreto-Lei/Del3689.htm>. Acesso em: 08 nov. 2018.

65 GIACOMOLLI, Nereu José. 0 devido processo penal: abordagem conforme a Constituição Federal e o Pacto de São José da Costa Rica: cases da Corte Interamericana, do Tribunal Europeu e do STF. São Paulo: Atlas, 2014. p. 181. 
o juiz aplicaria o in dubio pro reo ante dúvidas sobre pontos relevantes ao seu convencimento ${ }^{66}$.

No entanto, a avaliação da prova é um ato realizado pessoalmente pelo juiz que, considerando os elementos apresentados pelas partes, decidirá. ${ }^{67}$ Deste modo o sistema de valoração da prova é um método de limitação do poder jurisdicional, o qual surgiu primordialmente como "sistema legal de provas", conhecido também como sistema tarifado, onde a própria legislação previa a valoração de cada tipo de prova, sem haver a possibilidade de realizar a análise da especificidade de cada caso, sendo impositiva a valoração legal (a exemplo, a confissão como prova absoluta e o fato de existir o depoimento de uma só testemunha não ter valor) ${ }^{68}$.

O sistema mais antigo baseado na valoração probatória prevista na lei foi abolido com o surgimento do princípio da íntima convicção, o qual apresentou a valoração da prova processual calcada apenas na íntima convicção formada pelo juiz, sem que esta precisasse estar vinculada à provas constantes nos autos e nem mesmo necessitava que sua decisão viesse fundamentada de alguma maneira. A verdade jurídica advinha tão somente da convicção formada pelo juiz baseada nas provas colhidas e examinadas e até mesmo através de seu conhecimento pessoal, o julgamento era secundum conscientiam ${ }^{69}$.

Tendo em vista a radicalização de extremos dos dois sistemas anteriores, surge um terceiro sistema que se utiliza de preceitos

66 GIACOMOLLI, Nereu José. 0 devido processo penal: abordagem conforme a Constituição Federal e o Pacto de São José da Costa Rica: cases da Corte Interamericana, do Tribunal Europeu e do STF. São Paulo: Atlas, 2014. p. 182.

67 De CAMARGo ARAnHA, Adalberto José Q.T. Da Prova No Processo Penal . 5 ed. São Paulo: Saraiva, 1999. p. 8.

${ }_{68}$ LOPES JR, Aury. Direito processual penal. 9 ed. São Paulo: Saraiva, 2012. p. 561.

69 De CAMARgo ARAnHA, Adalberto José Q.T. Da Prova No Processo Penal . 5 ed. São Paulo: Saraiva, 1999. p. 75. 
destes dois. O sistema do "livre convencimento motivado" não possui valor probatório tarifado, porém também não tem a possibilidade de o juiz proferir sentença sem fundamentar sua decisão ${ }^{70}$.

0 artigo 155, do Código de Processo Penal, aliado à Exposição de Motivos $^{71}$ deste mesmo diploma, baliza o sistema adotado ao definir que o juiz estará livre para formar sua convicção, mas que esta será fundada através da apreciação das provas do processo. Afastando a taxatividade de valoração, concedendo liberdade à formação de convicção, porém limitando-a as provas coligidas. ${ }^{72}$ A legislação não consagra maior prestígio a uma ou outra prova do processo, as relativizando sob o critério do julgador de cada caso $^{73}$, porém restringe seu campo de fundamentação somente as

70 LOPES JR, Aury. Direito processual penal. 9 ed. São Paulo: Saraiva, 2012. p. 562.

71 VII - O projeto abandonou radicalmente o sistema chamado da certeza legal. Atribui ao juiz a faculdade de iniciativa de provas complementares ou supletivas, quer no curso da instrução criminal, quer a final, antes de proferir a sentença. Não serão atendíveis as restrições à prova estabelecidas pela lei civil, salvo quanto ao estado das pessoas; nem é prefixada uma hierarquia de provas: na livre apreciação destas, o juiz formará, honesta e lealmente, a sua convicção. A própria confissão do acusado não constitui, fatalmente, prova plena de sua culpabilidade. Todas as provas são relativas; nenhuma delas terá, ex vi legis, valor decisivo, ou necessariamente maior prestígio que outra. Se é certo que o juiz fica adstrito às provas constantes dos autos, não é menos certo que não fica subordinado a nenhum critério apriorístico no apurar, através delas, a verdade material. 0 juiz criminal é, assim, restituído a sua própria consciência. Nunca é demais, porém, advertir que livre convencimento não quer dizer puro capricho de opinião ou mero arbítrio na apreciação das provas. 0 juiz está livre de preconceitos legais na aferição das provas, mas não pode abstrairse ou alhearse ao seu conteúdo. Não estará ele dispensado de motivar a sua sentença. E precisamente nisto reside a suficiente garantia do direito das partes e do interesse social.(...) In: BRASIL. Decreto-lei no 3.689, de 3 de outubro de 1941. Exposição de Motivos do Código de Processo Penal. Diário Oficial [da] República Federativa do Brasil. Poder Executivo. Brasília, DF, 1941. In: Vade Mecum Penal: Penal, Processo Penal e Constituição. São Paulo: Saraiva, 2017. p. 225.

72 MIRABeTE, Julio Fabbrini. Processo Penal. 17 ed. São Paulo: Atlas, 2005. p. 285.

73 JUNIOR, Aury Lopes. Introdução crítica ao processo penal: fundamentos da instrumentalidade garantista. 3 ed. Rio de Janeiro: Lumen Juris, 2005. p. 276. 
provas dos autos sob o paradigma de que "o que não está nos autos não está no mundo" (quod non est in actis non est in hoc mundo) ${ }^{74}$.

Deste modo, se impõe a nova redação do artigo 155, do Código de Processo Penal, que além de que o juiz se baseará somente nas provas processuais que foram submetidas ao crivo do contraditório, prevê que, por óbvio ante o caráter antidemocrático, este não poderá fundar sua decisão em elementos colhidos em fase investigatória ${ }^{75}$.

Cabe salientar, que a expressão de "livre" convencimento, não diz respeito a uma construção de convicção sem limitações, mas sim que o julgador decidirá sem coação ou intervenção de interesses políticos, econômicos ou populares ${ }^{76}$, não deixando de fundamentar sua decisão expondo as condições que levaram à formação de seu convencimento.

A prova independente de sua relativização, em face da liberdade do julgador em valorar conforme sua convicção, é limitada pela imposição de fundamento das decisões judiciais calcada na Constituição Federal, em seu artigo 93, IX ${ }^{77}$, para que, justamente,

74 CAPEZ, Fernando. Curso de processo penal. 23 ed. São Paulo: Saraiva, 2016. Paginação Irregular. Disponível em: <http://assindelp.org.br/files/conteudo_arquivo/12005/fernando-capez---curso-de-processo-penal---2016.pdf>.

75 LIMA, Renato Brasileiro de. Manual de processo penal. 4 ed. Salvador: JusPodivm, 2014. Paginação Irregular. Disponível em: < https://forumdeconcursos. com/wp-content/uploads/wpforo/attachments/4032/174-Manual-de-Processo-Penal-Renato-Brasileiro-de-Lima-2016-Volume-Unico-4-Ed.pdf>.

76 LOPES JR, Aury. Direito processual penal. 9 ed. São Paulo: Saraiva, 2012. p. 562.

77 Art. 93. Lei complementar, de iniciativa do Supremo Tribunal Federal, disporá sobre o Estatuto da Magistratura, observados os seguintes princípios: (...)IX todos os julgamentos dos órgãos do Poder Judiciário serão públicos, e fundamentadas todas as decisões, sob pena de nulidade, podendo a lei limitar a presença, em determinados atos, às próprias partes e a seus advogados, ou somente a estes, em casos nos quais a preservação do direito à intimidade do interessado no sigilo não prejudique o interesse público à informação; (...) BRASIL. Constituição Federal de 1988. Disponível em: < http://www.planalto.gov.br/ccivil_03/constituicao/constituicaocompilado. htm>. Acesso em: 08 nov. 2018. 
analise-se a avaliação crítica individual feita pelo julgador sobre cada prova produzida ${ }^{78}$.

No entanto, a liberdade garantida ao julgador para formação de seu convencimento pode tornar-se uma forte arma do juiz contra o acusado, ao passo que, por vezes, a prova dos autos é deficitária, e a decisão será calcada somente nos elementos coligidos, e em sua grande maioria embasada na prova testemunhal, que apresenta-se no sistema brasileiro como principal meio de prova no processo ${ }^{79}$.

Acerca da prova testemunhal, Adalberto Aranha cita ensinamentos de Bentham, um dos reformadores contemporâneos de Beccaria:

As testemunhas são os olhos e os ouvidos da justiça. Desde que os homens existem e desde que têm a pretensão de fazer justiça hão valido das testemunhas como o mais fácil e comum meio de prova; sua importância no campo criminal é considerável; frequentemente é a única base das acusações ${ }^{80}$.

Cediço que a prova testemunhal é a mais comum dentro do processo penal e notoriamente àquela mais perigosa e falha dele, tendo em vista os diversos fatores que tendem a afetar a consciência do popular que fará o relato (muitas vezes totalmente alheio ao fato que se passa) partindo de suas percepções pessoais.

A testemunha, presente no ambiente do delito, contrai suas percepções através de seus sentidos, especialmente visão e audição ${ }^{81}$, os quais podem ser distorcidos e afetados, induzindo ao

78 LIMA, Renato Brasileiro de. Manual de processo penal. 4 ed. Salvador: JusPodivm, 2014. Paginação Irregular. Disponível em: < https://forumdeconcursos. com/wp-content/uploads/wpforo/attachments/4032/174-Manual-de-Processo-Penal-Renato-Brasileiro-de-Lima-2016-Volume-Unico-4-Ed.pdf>.

79 LOPES JR, Aury. Direito processual penal. 9 ed. São Paulo: Saraiva, 2012. p. 650

80 De CAMArgo ARAnhA, Adalberto José Q.T. Da Prova No Processo Penal . 5 ed. São Paulo: Saraiva, 1999. p. 138.

81 MIRABETE, Julio Fabbrini. Processo Penal. 17 ed. São Paulo: Atlas, 2005. p. 318. 
erro, dependendo do modo em que visualizou a ação delituosa (distância e ângulo), da opinião pessoal acerca do delito praticado, da maneira em que é inquirido, bem como seu estado emocional no momento que presenciou o delito e no momento em que prestou seu depoimento ${ }^{82}$.

Gustavo Ávila e Dirceu Siqueira referenciam lições de Franco Cordero, que leciona acerca da seletividade dos canais sensoriais que levam à formação da compreensão dos fatos de cada testemunha, o qual se limita à percepções que está acostumado a presenciar (à exemplo o guarda de trânsito e o pedestre presente) ou diretamente ligadas ao estado emocional da testemunha. Além disto, refere como fator determinante a maneira em que irá, e a capacidade que tem a testemunha externar em palavras o que captou visualmente ${ }^{83}$.

A lei prevê que toda pessoa pode ser testemunha (a doutrina a define como um terceiro desinteressado e capaz que tenha conhecimento dos fatos $)^{84}$ e, para que reduzam-se os riscos de ocorrer um depoimento contaminado de inverdades, a legislação se encarregou de tornar obrigatória a prestação de compromisso de dizer a verdade ${ }^{85}$. 0 ato em si não impede que a testemunha

82 De CAmargo aranha, Adalberto José Q.T. Da Prova No Processo Penal . 5 ed. São Paulo: Saraiva, 1999. p. 139.

${ }^{83}$ SIQUEIRA, Dirceu Pereira; DE ÁVILA, Gustavo Noronha. Acesso à justiça e os direitos da personalidade: elementos para a formação da prova testemunhal no novo código de processo penal, levando a psicologia do testemunho à sério!. Canoas: Revista Eletrônica Direito e Sociedade-REDES, 2018. v. 6. p. 63. Disponível em: <https://www.academia.edu/36742736/ Elementos_para_a_Forma\%C3\%A7\%C3\%A3o_da_Prova_Testemunhal_no_Novo_C\%C3\%B3digo_de_Processo_Penal_2018_?auto=download $>$.

84 LIMA, Renato Brasileiro de. Manual de processo penal. 4 ed. Salvador: JusPodivm, 2014. Paginação Irregular. Disponível em: < https://forumdeconcursos. com/wp-content/uploads/wpforo/attachments/4032/174-Manual-de-Processo-Penal-Renato-Brasileiro-de-Lima-2016-Volume-Unico-4-Ed.pdf>.

85 Art. 203. A testemunha fará, sob palavra de honra, a promessa de dizer a verdade do que souber e Ihe for perguntado, devendo declarar seu nome, sua idade, seu estado e sua residência, sua profissão, lugar onde exerce sua atividade, se é parente, e em que grau, de alguma das partes, ou quais suas 
profira inverdades, portanto é uma formalidade imposta ${ }^{86} .0$ dever de dizer a verdade serve para que a testemunha não oculte a verdade nem deixe de se manifestar ao falso ${ }^{87}$

As exceções ao dever de prestar compromisso, são aquelas com determinado grau de parentesco com o acusado, ou ainda os menores de quatorze anos e os deficientes mentais, conforme previsão dos artigos 206 e 208, respectivamente, do Código de Processo Penal. Aqueles para que não comprometa a paz e harmonia entre as relações familiares, e estes por terem reduzido seu discernimento das consequências em violar o compromisso ${ }^{88}$.

Àquele que, devidamente compromissado (e estritamente àquele que prestou o compromisso formal, não abrangendo os que deixam de prestá-lo e são ouvidas como informantes), deixar de cumprir com a verdade, estará sujeito a responder pelo crime de falso testemunho ${ }^{89}$, conforme previsão legal que determina no artigo 211, do Código de Processo Penal ${ }^{90}$, que ao proferir a

relações com qualquer delas, e relatar o que souber, explicando sempre as razões de sua ciência ou as circunstâncias pelas quais possa avaliar-se de sua credibilidade. BRASIL. Decreto-lei no 3.689, de 3 de outubro de 1941. Código de Processo Penal. Diário Oficial [da] República Federativa do Brasil. Poder Executivo. Brasília, DF, 1941. Disponível em: < http://www.planalto. gov.br/ccivil_03/Decreto-Lei/Del3689.htm>. Acesso em: 08 nov. 2018.

86 LOPES JR, Aury. Direito processual penal. 9 ed. São Paulo: Saraiva, 2012. p. 659.

87 DE CAMARgo ARAnHA, Adalberto José Q.T. Da Prova No Processo Penal . 5 ed. São Paulo: Saraiva, 1999. p. 151.

88 LOPES JR, Aury. Direito processual penal. 9 ed. São Paulo: Saraiva, 2012. p. 659.

89 Art. 342. Fazer afirmação falsa, ou negar ou calar a verdade como testemunha, perito, contador, tradutor ou intérprete em processo judicial, ou administrativo, inquérito policial, ou em juízo arbitral (...) In: BRASIL. Decreto-lei no 2.848, de 7 de dezembro de 1940. Código Penal. Diário Oficial [da] República Federativa do Brasil. Poder Executivo. Brasília, DF, 1940. Disponível em: < http://www.planalto.gov.br/ccivil_03/decreto-lei/ Del2848compilado.htm>. Acesso em: 08 nov. 2018.

90 Art. 211. Se o juiz, ao pronunciar sentença final, reconhecer que alguma testemunha fez afirmação falsa, calou ou negou a verdade, remeterá cópia do depoimento à autoridade policial para a instauração de inquérito. (...) In: BRASIL. Decreto-lei no 3.689, de 3 de outubro de 1941. Código de Processo Penal. Diário Oficial [da] República Federativa do Brasil. Poder 
sentença, se o juiz reconhecer que alguma testemunha fez falsa afirmação, calou-se ou negou a verdade, deverá encaminhar cópia do depoimento à autoridade policial para apuração do delito ${ }^{91}$.

Este é um mecanismo que o sistema se utiliza para intimidar os testemunhos afetados por inverdades, ao ponto que não interfira na busca da "verdade real", a qual é desconstruída por Aury Lopes Jr. que demonstra a impossibilidade em construirse uma verdade real de um fato passado, tendo em vista que o processo busca realizar a reconstrução de um fato histórico, e que esta finalidade nunca é atingida de forma perfeita pelo fato da incidência do tempo transcorrido ${ }^{92}$.

Analisa o autor, especificamente a prova testemunhal, pois é ela a principal prova utilizada no processo penal, e depende unicamente da memória de quem narra, a qual é extremamente frágil e contaminável por fatos externos aos ocorridos. A produção probatória decorre somente do imaginário daquele que presenciou, e não existindo mais fatos reais, apenas baseia-se no que sua memória encarregou-se de guardar ${ }^{93}$.

Deste modo a cognição daquele que leva o conhecimento ao Juiz é bastante contaminada, seja por incidência da contaminação de memórias decorrentes de outros acontecimentos, ou ainda pelo simples fato da decorrência do tempo (binômio tempo/ velocidade) onde os pensamentos se desprendem da memória ${ }^{94}$.

Executivo. Brasília, DF, 1941. Disponível em: < http://www.planalto.gov. br/ccivil_03/Decreto-Lei/Del3689.htm>. Acesso em: 08 nov. 2018.

91 MIRABETE, Julio Fabbrini. Processo Penal. 17 ed. São Paulo: Atlas, 2005. p. 322.

92 JUNIOR, Aury Lopes. Introdução crítica ao processo penal: fundamentos da instrumentalidade garantista. 3 ed. Rio de Janeiro: Lumen Juris, 2005. p. 267.

93 JUNIOR, Aury Lopes. Introdução crítica ao processo penal: fundamentos da instrumentalidade garantista. 3 ed. Rio de Janeiro: Lumen Juris, 2005. p. 267.

94 JUNIOR, Aury Lopes. Introdução crítica ao processo penal: fundamentos da instrumentalidade garantista. 3 ed. Rio de Janeiro: Lumen Juris, 2005. p. 268. 
De outro lado, temos a figura do ofendido, que também depõe, mas não é visto no nosso ordenamento jurídico como uma testemunha de fato. Tem seu tratamento legal em capítulo apartado ao das testemunhas no Código de Processo Penal, ademais, sua maior divergência com a testemunha, está calcada no fato de que esta não tem o dever de prestar compromisso ${ }^{95}$.

0 ofendido, que é o titular do bem jurídico lesado ou ameaçado, tampouco é computado no rol de testemunhas e nem mesmo necessita ser arrolado, presumindo como um dever do juiz em realizar sua oitiva ${ }^{96}$. Porém, a força probatória de suas declarações é igualmente válida, inclusive podendo ser a única prova capaz de ensejar sentença condenatória, se consonante com os demais elementos ${ }^{97}$.

Todavia, incumbe ao juiz valorar a prova decorrente das declarações do ofendido, que naturalmente poderá apresentarse com certo prejuízo, pois ele, o verdadeiro interessado no litígio, por vezes poderá estar motivado por sentimento de ódio ou vingança por ter visto lesionado seu bem jurídico. Ademais o cuidado maior deve haver quando o delito for cometido na clandestinidade, onde o único presente é a própria vítima ${ }^{98}$.

Feitas as ponderações acerca do valor probatório, cediço que o depoimento que o ofendido presta não pode ser tão minuciosamente detalhado por quaisquer outro espectador do delito, deste modo, torna-se forte prova quando sua palavra vem corroborada por outros elementos probatórios dos autos. ${ }^{99}$

95 MIRABETE, Julio Fabbrini. Processo Penal. 17 ed. São Paulo: Atlas, 2005. p. 315.

96 DE CAMARgo ARAnHA, Adalberto José Q.T. Da Prova No Processo Penal . 5 ed. São Paulo: Saraiva, 1999. p. 132.

97 MIRABETE, Julio Fabbrini. Processo Penal. 17 ed. São Paulo: Atlas, 2005. p. 315.

98 MIRABETE, Julio Fabbrini. Processo Penal. 17 ed. São Paulo: Atlas, 2005. p. 317.

99 MIRABETE, Julio Fabbrini. Processo Penal. 17 ed. São Paulo: Atlas, 2005. p. 317. 
Aproximando-se cada vez mais dos riscos inerentes ao depoimento de uma vítima, trataremos deste certame no capítulo seguinte.

\section{A INCIDÊNCIA DE FALSAS MEMÓRIAS E OS DANOS NO DEPOIMENTO JUDICIAL}

No capítulo anterior abordamos brevemente o contexto do valor probatório da palavra do ofendido, que em clássicas obras, não deixam os autores de mencionar sua fragilidade, ante a posição de quem presta o depoimento.

0 valor probatório da palavra da vítima é ponto problemático enfrentado pelo judiciário, tendo em vista, que ela está altamente contaminada pelo próprio delito, visto que o depoente fez parte deste. $\mathrm{O}$ que, de fato, acarreta efeitos em seu método de expor o fato delituoso, tanto de modo benéfico ao acusado, por temê-lo, ou para prejudicá-lo, por motivo de vingança alheia ao fato ou inerente a ele pelo fato de tê-lo sofrido. As alegações tornam-se mais suscetíveis a mentiras, ao passo que, como referimos no capítulo anterior, o ofendido deixa de prestar compromisso perante o juízo ${ }^{100}$.

Ante a dispensa de prestação de compromisso, a credibilidade do depoimento torna-se evidentemente menor, o que leva ao entendimento que de praxe seja vedada a sentença condenatória calcada somente no depoimento do ofendido. Contudo, a jurisprudência prevê como exceções os delitos cometidos contra o patrimônio com violência ou grave ameaça, e também crimes sexuais, tendo em vista que em sua grande maioria são delitos praticados com absoluta clandestinidade, sem que haja presença de outras testemunhas. ${ }^{101}$ Analisaremos neste capítulo a fragilida-

${ }^{100}$ LOPES JR, Aury. Direito processual penal. 9 ed. São Paulo: Saraiva, 2012. p. 649.

101 LOPES JR, Aury. Direito processual penal. 9 ed. São Paulo: Saraiva, 2012. p. 650 . 
de deste depoimento, em especial quando prestados por crianças vítimas de estupro, o qual não detém previsão legal de métodos especiais para sua colheita.

O Brasil foi surpreendentemente, considerado o país com maiores índices de violência infantil no mundo, em pesquisa realizada no ano de 2016, muito embora seu PIB (Produto Interno Bruto) não seja comparado aos mais baixos do mundo (fator fortemente atrelado aos altos índices de violência) ${ }^{102}$. A violência empregada contra crianças, segundo a Organização das Nações Unidas (ONU) em pesquisa realizada já no ano de 2006, constatou ser um dos maiores problemas globais e que este é um assunto fortemente ocultado, tendo como um dos motivos a não confiabilidade de relatos de violência advindos de infantes ${ }^{103}$.

0 processo penal se torna carente de embasamento probatório, ao passo em que vestígios inexistem para fortificar teses. Em um estudo realizado no Estados Unidos por Astrid Heger, dentre 2.384 crianças que chegaram em um hospital local com relato de abuso sexual, somente $4 \%$ delas possuíam vestígios físicos ${ }^{104}$, o que demonstra, o quão frágil torna-se a prova nos casos levados ao judiciário, que, por este motivo, acabam baseando sentenças somente em prova testemunhal, ou somente, e ainda mais grave, na palavra do ofendido.

No momento em que o depoimento pessoal de uma criança vítima de violência torna-se o único elemento probatório para avaliação do juiz, necessário que o Direito funda seus conheci-

102 Disponível em: http://prioridadeabsoluta.org.br/wp-content/ uploads/2016/05/global-partnership.pdf. p. 10. Acesso em 15 de novembro de 2018.

103 STEIN, Lilian M. Falsas memórias: Fundamentos científicos e suas aplicações clínicas e jurídicas. Porto Alegre: Artmed, 2010. p. 157.

104 HEGER, Astrid, TICSON, Lynne, VELASQUEZ, Oralia, BERNIER, Raphael. Children referred for possible sexual abuse: medical findings in 2384 children. Child abuse and Neglect, 2002. v. 26, p. 645-659. In: STEIN, Lilian M. Falsas memórias: Fundamentos científicos e suas aplicações clínicas e jurídicas. Porto Alegre: Artmed, 2010. p. 157. 
mentos, com aqueles advindos da Psicologia ${ }^{105}$, tendo em vista que o exercício de recordar para relatar um fato violento pode ser perturbador para a mente daquele que nem tem por completo desenvolvida sua capacidade psicológica.

Esta fusão das áreas do conhecimento ocorre ao passo que para o Direito a aferição precisa de um relato necessita ser realizada para descobrir sua veracidade e assegurar segurança jurídica em julgamentos que se valerão da prova produzida.

Alguns estudos de origem naturalística constatam que as recordações de eventos estressantes sofridos por crianças tendem a ser menos esquecidos e mais fixados na memória devido à maneira que tocam as emoções fortemente ${ }^{106}$. Porém, em um estudo experimental realizado por Douglas Peters, com crianças que sofreram uma simulação de assalto, demonstrou que estas recordaram menos detalhes do evento do que àquelas que não sofreram este trauma, e só observaram uma pessoa estranha adentrar no recinto sem cometer nenhum roubo ${ }^{107}$. 0 que demonstra que o ato violento sofrido causou alterações emocionais que interferiram no armazenamento de informações.

Acerca da emoção e memória, importante colocação de Gustavo Noronha de Ávila ${ }^{108}$ :

“Um crime possui conteúdo potencialmente traumático para a testemunha que o presencia, no entanto, a sua "fixação" dependerá de como o indivíduo o percebe. Desta forma, a emoção pode

105 STEIN, Lilian M. Falsas memórias: Fundamentos científicos e suas aplicações clínicas e jurídicas. Porto Alegre: Artmed, 2010. p. 158.

106 STEIN, Lilian M. Falsas memórias: Fundamentos científicos e suas aplicações clínicas e jurídicas. Porto Alegre: Artmed, 2010. p. 162.

107 PETERS, Douglas P. (1991). The influence of stress and arousal on the child witness. In J. Doris (Ed.), The suggestibility of children's recollections (pp.6076). APUD STEIN, Lilian M. Falsas memórias: Fundamentos científicos e suas aplicações clínicas e jurídicas. Porto Alegre: Artmed, 2010. p. 165.

108 ÁVILA, Gustavo Noronha de. Fraturas do sistema penal: o sintoma das falsas memórias na prova testemunhal. Porto Alegre: PUCRS, 2013. p. 83. 
servir tanto para facilitar a rememoração de uma lembrança, como para reprimi-la, variando de acordo com aquele que a evoca".

Gilberto Thums ao tratar do tempo da prova e sua valoração pelo juiz, refere ser a questão temporal importante fator que definirá a qualidade dos depoimentos em Juízo. 0 transcurso temporal entre a data do fato, e o dia em que o depoimento será prestado na instrução do processo penal pode representar anos, o que invariavelmente pode causar efeitos nefastos na memória daquele que presenciou o evento, na medida em que as lembranças vão enfraquecendo por questões biológicas ou por influências psíquicas ${ }^{109}$. Aury Lopes Júnior questiona que se, por vezes, ao fim do dia não conseguimos recordar alguma atividade que realizamos no turno da manhã, como confiar em um relato baseado em recordações de um fato ocorrido há meses ou anos? ${ }^{110}$

Deixando de lado o caráter biológico das alterações em nossa memória, será acerca das influências psicológicas que trataremos daqui em diante, estudando a incidência do fenômeno das falsas memórias na consciência da vítima.

A falsa memória difere-se da mentira ao passo que na primeira, o afetado, de fato, crê que o fato narrado por certo ocorreu consigo, externando sua versão dos fatos com convicção, estando inconsciente da não veracidade, e na segunda ao externar uma inverdade, o agente tem consciência de que ele mesmo está manipulando a versão. Sendo os dois casos altamente prejudiciais à instrução de um processo, a preocupação com a incidência de uma falsa memória se torna maior na medida em que sua constatação é extremamente difícil ${ }^{111}$.

109 THUMS, Gilberto. Sistemas Processuais Penais. Rio de Janeiro: Lumen Juris, 2006. p 51.

110 LOPES JUNIOR, Aury. Você confia na sua memória? Infelizmente, o processo penal depende dela. [s.l.]: CONJUR, 2014. Paginação Irregular.

111 LOPES JR, Aury. Direito processual penal. 9 ed. São Paulo: Saraiva, 2012. p. 670-671. 
Elisabeth Loftus, pesquisadora americana e grande autoridade na atualidade acerca do fenômeno, retrata o efeito da informação incorreta na criação de falsas memórias e ainda o efeito da sugestionabilidade. A autora não deixa de salientar que em seus estudos de casos, evidente que as recordações são mais facilmente modificadas quando o há o transcurso temporal maior entre o fato e o relato, pois há o enfraquecimento da memória ${ }^{112}$.

Loftus relata que após a vivência de um fato, se implementadas informações sugestivas que diferem da realidade, tendem os agentes a modificarem suas lembranças, como retrata no caso do sinal de trânsito, onde indivíduos visualizaram uma simulação de acidente automobilístico onde havia uma placa com sinal de "pare", e após este momento, metade dos expectadores recebeu a sugestão de que a placa indicativa era de passagem preferencial. 0 resultado foi que àqueles que receberam a sugestão tenderam todos à relatar que a placa indicativa era de passagem preferencial, enquanto os que não receberam a sugestão eram mais precisos em indicar o sinal de trânsito certo (pare).$^{113}$

Acerca do efeito da informação falsa, a Autora narra o caso "perdidos no shopping", onde indivíduos recebem relatos de um fato ocorrido quando crianças em que se perderam em um shopping, o qual, foram informados, teria sido narrado por um familiar (informação falsa). Da pesquisa concluiu Loftus que vários indivíduos expostos ao caso "recordaram-se" do fato, o que demonstra que a implantação de falsas memórias pode recair até na criação de "memórias" que nunca ocorreram. A autora ressalta

112 LOFTUS, Elizabeth F. Criando falsas memórias. Revista Scientific American, ano, v. 3, 2004. Paginação Irregular. Disponível em: <http://ateus.net/ artigos/miscelanea/criando-memorias-falsas/>.

113 LOFTUS, Elizabeth F. Criando falsas memórias. Revista Scientific American, ano, v. 3, 2004. Paginação Irregular. Disponível em: <http://ateus.net/ artigos/miscelanea/criando-memorias-falsas/>. 
que nestes casos, quando a informação falsa é passada por um familiar, a influência nas memórias tende a ser mais recorrente ${ }^{114}$.

Diante da estima que crianças tendem a ter por adultos, devido a situação de superioridade destes na sociedade (por serem os educadores, os patronos, os detentores de maior sapiência), acabam por tornarem-se vulneráveis às sugestões e informações apresentadas por estes, que com facilidade podem implantar suas visões na mente das crianças. ${ }^{115}$

Cumpre salientar o emblemático "Caso Escola Base" ocorrido no Brasil, no Estado de São Paulo, em 1994, onde mães de duas crianças estudantes da Escola, registraram ocorrência de abuso sexual cometido pelos donos e professores fora das dependências da instituição, mas em horário de aula. As crianças relatavam momentos em uma cama redonda com pessoas nuas que tiravam fotos suas ${ }^{116}$.

Após a divulgação de um laudo inconclusivo acerca de terem as crianças sofrido ou não abuso sexual, a imprensa brasileira tratou de expor a notícia, de maneira abusiva e mentirosa, valendo-se do alto nível de repúdio que tem a população ante este tipo de delito, incitando que o abuso teria de fato acontecido, causando uma verdadeira onda de manchetes sensacionalistas acerca do caso pelo país. 0 que caiu por terra tempo depois, ao ser o inquérito policial arquivado, pois além da insuficiência probatória, a laceração anal referida no laudo ficou comprovada ter sido causada por problemas intestinais nas crianças ${ }^{117}$.

114 LOFTUS, Elizabeth F. Criando falsas memórias. Revista Scientific American, ano, v. 3, 2004. Paginação Irregular. Disponível em: <http://ateus.net/ artigos/miscelanea/criando-memorias-falsas/>.

115 FEIX, Leandro da Fonte. Efeito da emoção na memória de crianças. Porto Alegre: PUCRS, 2008. p. 29.

116 LOPES JR, Aury. Direito processual penal. 9 ed. São Paulo: Saraiva, 2012. p. 674.

117 LOPES JR, Aury. Direito processual penal. 9 ed. São Paulo: Saraiva, 2012. p. 675. 
Com o aumento dos estudos acerca da implantação de falsas memórias, percebeu-se a importância de seus reflexos na área jurídica, principalmente sob a perspectiva do aumento de relatos de infantes violentados, onde mais do que nenhuma outra área, necessita que relatos sejam registrados de modo completo, consistente e transparente ${ }^{118}$.

Muito embora, no Brasil sejam precários os estudos no campo da psicologia forense, no âmbito internacional a pesquisa vem ocorrendo há muito tempo, e prova cada vez mais, que a memória de eventos traumáticos e violentos (neste caso, estupro de vulnerável) sofridos por crianças merece atenção especial no âmbito jurídico, uma vez que o delito, em sua maioria, não deixa vestígios físicos e nem sempre resulta em danos psíquicos de fácil diagnóstico ${ }^{119}$.

Imperiosa é a realização de estudos, aprofundamento de conhecimento e ajuste nos métodos de colher depoimento de uma vítima de abuso sexual, pois além do trauma sofrido por ter sido submetido à um ato violento, o exercício de recordar e relatar como se deram os fatos, é inerente que causa dor e sofrimento ao infante que tem de expor situações ligadas à sua intimidade. ${ }^{120}$

Além das falsas memórias já gravadas na memória da criança, seja por uma sugestão externa, informação incorreta ou até proveniente de uma distorção interpretativa, outro ponto crítico que pode interferir na consistência do depoimento é o modo em que as partes ou o juiz formulam suas perguntas à parte. E é neste momento que o papel do entrevistador se torna ponto crucial, pois este buscará, através da formulação de suas questões, um relato preciso e coincidente com a realidade dos fatos vividos pelo depoente, sem que o modo empregado para

118 FEIX, Leandro da Fonte. Efeito da emoção na memória de crianças. Porto Alegre: PUCRS, 2008. p. 19.

119 FEIX, Leandro da Fonte. Efeito da emoção na memória de crianças. Porto Alegre: PUCRS, 2008. p. 20.

120 STEIN, Lilian M. Falsas memórias: Fundamentos científicos e suas aplicações clínicas e jurídicas. Porto Alegre: Artmed, 2010. p. 158. 
questionar o induza a uma resposta distorcida, podendo até criar uma falsa memória ${ }^{121}$.

E é sob este ponto frágil constatado pela ciência da psicologia, que em busca da redução de danos na entrevista, países Europeus e estados americanos implementaram em seus tribunais o sistema de gravações dos depoimentos prestados por crianças, para que posteriormente sejam avaliados por peritos que observarão a possibilidade de a técnica empregada ter provocado distorções na narrativa. ${ }^{122}$

No Brasil, embora já exista em andamento projeto para redução de danos em depoimentos (o qual trataremos a seguir), não há exigência legal de aplicação de alguma sistemática preparada para este controle. 0 que acaba por causar grandes riscos nas recorrentes sentenças de estupro de vulnerável, onde o juiz terá de decidir se toma como verdade a versão da vítima ou do réu. Deste modo, torna-se o embate na mente do julgador: atender ao direito constitucional de liberdade do cidadão ou acolher o grito de socorro da criança vítima? ${ }^{123}$

Tendo em vista inexistir previsão legal especial para colheita de depoimento infantil, os julgadores tendem a seguir seus próprios entendimentos, utilizando-se de alguns princípios, acerca da valoração da palavra da vítima. Alguns entendem como suficiente o método da inquirição judicial para chegar ao decreto condenatório ${ }^{124}$, vejamos trecho de entendimento da Sétima Câmara Cível do Tribunal de Justiça do Rio Grande do Sul:

121 STEIN, Lilian M. Falsas memórias: Fundamentos científicos e suas aplicações clínicas e jurídicas. Porto Alegre: Artmed, 2010. p. 209.

122 PISA, Osnilda. Psicologia do testemunho: os riscos na inquirição de crianças. Porto Alegre: PUCRS, 2006. p. 11.

123 PISA, Osnilda. Psicologia do testemunho: os riscos na inquirição de crianças. Porto Alegre: PUCRS, 2006. p. 11.

124 AZAMBUJA, Maria Regina Fay de. Violência sexual intrafamiliar e produção de prova da materialidade: proteção ou violação de direitos da criança? Porto Alegre: PUCRS, 2010. p.220. 
“(...) Ora, é sabido que a palavra da vítima, especialmente nos crimes contra a liberdade sexual, que geralmente ocorrem na clandestinidade, longe da presença de testemunhas e da vigilância de autoridades, detém considerável credibilidade quando prestada de forma harmônica, considerando também que, tais crimes, muitas vezes não deixam vestígios no corpo da vítima, principalmente quando transcorrido um longo período de tempo entre a ocorrência do ato e a perícia realizada(.... $)^{\prime 125}$

De outro modo, existem aqueles que entendem ser frágil e insuficiente a unicidade da palavra da vítima inquirida, para ensejar uma condenação, e deste modo decidem:

“O conjunto probatório não empresta a certeza necessária para autorizar a condenação do acusado pela prática do delito de estupro de vulnerável. As contradições existentes nos depoimentos da vítima deixam margem para dúvidas quanto à ocorrência dos fatos. A palavra da vítima assume especial relevância para fins de aferição da efetiva existência dos abusos, especialmente quando estes, da forma como são praticados, não deixam vestígios, desde que confortada com outros elementos de prova. Havendo, contudo, como na hipótese vertida, fortes dúvidas sobre a ocorrência dos fatos, o relato deve ser sopesado com reservas. Diante de tais circunstâncias, a aplicação dos princípios da presunção de inocência e do in dubio pro reo é medida impositiva. Absolvição decretada" ${ }^{126}$.

E foi partir de dificuldades advindas de suas próprias experiências diárias ao confrontar-se com casos de abuso sexual, que o magistrado gaúcho José Antônio Daltoé Cezar, criou o projeto "Depoimento sem Dano" no ano de 2003, com o intuito da

125 Agravo № 70078669793, Sétima Câmara Cível, Tribunal de Justiça do RS, Relator: Liselena Schifino Robles Ribeiro, Julgado em 29/08/2018.

126 Apelação Crime № 70078199247, Quinta Câmara Criminal, Tribunal de Justiça do RS, Relator: Lizete Andreis Sebben, Julgado em 12/09/2018. 
criação de provas confiáveis e robustas no processo, em busca de um depoimento fidedigno e tranquilo da criança vítima de abuso sexual, tendo em vista sua unicidade por recorrentes vezes nestes $\operatorname{casos}^{127}$.

O magistrado baseou-se na ideia da criação de uma Câmara de Gesel (sala de vidro espelhada unidirecional utilizada pela psicanálise) de modo que as outras partes teriam acesso para garantir o contraditório e ampla defesa. Porém, ante as dificuldades estruturais encontradas para sua instalação e a precariedade de recursos oferecidos pelo Tribunal na época, Cezar adaptou sua ideia em equipar uma sala com aparelhos de som e imagem que se conecte com a sala de audiências ${ }^{128}$.

0 projeto foi posto em prática pela primeira vez no dia 06 de maio de 2003, na $2^{\text {a }}$ Vara da Infância e da Juventude de Porto Alegre $^{129}$, e consistia na ideia de afastar a criança ou o adolescente, vítima de abuso sexual, da sala de audiências, a fim de colher seu depoimento em um ambiente especialmente acolhedor através de profissionais competentes para tanto (psicólogos ou assistentes sociais) ${ }^{130}$.

A sistemática prevista no projeto inicia-se já no acolhimento da criança que comparecerá ao Foro com antecedência mínima de trinta minutos, para evitar que esta e o réu encontrem-se nas dependências do local. Esta medida, por mais singela que seja,

127 CEZAR, José Antônio Daltoé. Depoimento sem dano: uma alternativa para inquirir crianças e adolescentes nos processos judiciais. Porto Alegre: Livraria do Advogado, 2007. p. 59-60.

128 CEZAR, José Antônio Daltoé. Depoimento sem dano: uma alternativa para inquirir crianças e adolescentes nos processos judiciais. Porto Alegre: Livraria do Advogado, 2007. p. 61.

129 CEZAR, José Antônio Daltoé. Depoimento sem dano: uma alternativa para inquirir crianças e adolescentes nos processos judiciais. Porto Alegre: Livraria do Advogado, 2007. p. 63.

130 CEZAR, José Antônio Daltoé. Depoimento sem dano: uma alternativa para inquirir crianças e adolescentes nos processos judiciais. Porto Alegre: Livraria do Advogado, 2007. p. 66. 
evita o abalo psicológico da vítima que possa comprometer o seu depoimento, o que não raras vezes já fora constatado. ${ }^{131}$

As demais partes do processo, presentes na sala de audiência, terão acesso à imagem e som da sala em que o profissional técnico estará realizando a entrevista com o infante, tendo em vista que este terá o papel de "traduzir" as questões formuladas em tempo real pelas partes, para uma linguagem familiarizada da criança ${ }^{132}$.

A mídia gravada na sala de entrevista será copiada em um disco e juntada aos autos para que as partes e o magistrado tenham a possibilidade de revê-la quando desejarem. Ademais, inclusive, será remetido juntamente ao Tribunal em caso de recurso interposto, tendo em vista que as emoções externadas pela criança não podem ser transferidas para o papel $^{133}$.

Contudo, além de reduzir os danos do depoimento que acarretam insegurança sob o ponto jurídico, a técnica de utilizar-se de um sistema alternativo que vise o bem estar da criança, reduzirá também o próprio estresse psicológico da criança que, por vezes, estará encoberta de medo, vergonha, raiva, dor e sofrimento ao ter de submeter-se à rememoração do ato violento sofrido. ${ }^{134} 0$ que garante também o direito constitucional calcado no melhor interesse da criança previsto intrinsecamente no artigo 227 da Constituição Federal, e no Estatuto da Criança e do Adolescente.

131 CEZAR, José Antônio Daltoé. Depoimento sem dano: uma alternativa para inquirir crianças e adolescentes nos processos judiciais. Porto Alegre: Livraria do Advogado, 2007. p. 68.

132 CEZAR, José Antônio Daltoé. Depoimento sem dano: uma alternativa para inquirir crianças e adolescentes nos processos judiciais. Porto Alegre: Livraria do Advogado, 2007. p. 69.

${ }^{133}$ CEZAR, José Antônio Daltoé. Depoimento sem dano: uma alternativa para inquirir crianças e adolescentes nos processos judiciais. Porto Alegre: Livraria do Advogado, 2007. p. 62.

134 SANTOS, Benedito Rodrigues dos; GONÇALVES, Itamar Batista (Ed.). Depoimento sem medo (?): culturas e práticas não-revitimizantes: uma cartografia das experiências de tomada de depoimento especial de crianças e adolescentes. [s.l.]: Childhood Brasil (Instituto WCF-Brasil), 2009. Paginação Irregular. 
O depoimento danoso pode deixar de explanar os fatos como realmente se deram, e eximir o réu de uma condenação que seria necessária, ou ainda, e tragicamente, é possível que o infante traga uma versão fantasiosa e criminosa, que enseje a condenação injusta de alguém.

Ante a alta reprovabilidade social que possui o delito de estupro de vulnerável, neste caso, imperioso que seja dada maior relevância à aplicabilidade do princípio constitucional in dubio pro reo, tendo em vista que somente o fato de submeter um indivíduo a um processo criminal já é uma punição por si só. Senão, vejamos, a exemplo o caso aqui explicitado acerca dos professores e proprietários da Escola Base de São Paulo, onde sequer chegou a existir processo, apenas atos investigatórios, o que fora de modo suficiente para acabar com a profissão e a estima social dos investigados.

\section{CONSIDERAÇÕES FINAIS}

O Estado, como titular do direito de punir, instituiu o processo penal através da Constituição Federal e o regulou no Código de Processo Penal, para pôr limites ao seu próprio jus puniendi, e o delegou ao Poder Judiciário para que exerça tal função em seu nome, pois a partir do momento em que há o cometimento de um delito, seu direito torna-se um dever de punir o delinquente, para a eficaz proteção da sociedade.

0 processo, analisado sob a perspectiva de sua instrumentalidade como meio de aplicação do direito penal material, é visto como objeto imprescindível entre o cometimento de um delito e a pena a ser aplicada. Ademais, é através deste que é efetivado o caráter democrático do processo ao passo que garante o contraditório e a ampla defesa.

Todavia, o estudo dos sistemas processuais, mostrou-nos que embora o sistema adotado pelo Brasil seja o acusatório (garantidor pleno de igualdade entre as partes), o processo penal 
é contaminado por diversos traços inquisitórios na medida em que, além de ser possibilitado ao juiz a produção probatória, este tem livre acesso aos autos do inquérito policial, que é construído de modo totalmente inquisitório, e acompanha os autos do processo judicial. Razão pela qual, é inerente que as provas produzidas em fase policial (sem observância de contraditório e ampla defesa) afetem diretamente o convencimento do juiz que ao prolatar sentença não poderia basear seus argumentos com base em prova obtida no inquérito, mas que com um bom argumento disfarçado pode e consegue utilizar-se deste, alegando que as provas policiais vieram "corroboradas" na instrução processual.

Tendo em vista que a avaliação da prova é um ato realizado pessoalmente pelo juiz, o sistema de valoração da prova adotado pelo ordenamento jurídico é de suma importância na medida em que o julgador deverá valorar as provas de acordo com seu livre convencimento formado a partir dos elementos colhidos nos autos, desde que devidamente motivado em ato sentencial. 0 que traz ao magistrado a delicada e importante responsabilidade de decidir quando exposto à um conjunto probatório baseado apenas em testemunhos pessoais.

A fragilidade da prova testemunhal apresenta-se como ponto problemático no processo penal, tendo em vista que esta depende apenas da memória de quem narrará o fato criminoso e histórico, e por diversas vezes consta como único elemento probatório em um processo judicial.

E é sob os meandros da busca da verdade, que a pesquisa torna-se ainda mais estreita ao analisar o depoimento da criança vítima de estupro de vulnerável e relacioná-lo com o fenômeno das falsas memórias, o qual tem grande incidência na memória dos infantes que possuem capacidade psíquica reduzida e em desenvolvimento. Ocorrendo por uma sugestão externa ou uma informação incorreta passada, a falsa memória pode decorrer de 
uma distorção de um fato ou até mesmo pode incorrer na criação de uma vívida memória de um fato jamais existente.

0 fato é que, independente da incidência do fenômeno, o depoimento da vítima é deficitário por natureza, tendo em vista sua qualidade de sujeito ofendido que viu violada sua intimidade e possivelmente estará coberta de emoções e confusões sentimentais, as quais podem ser manipuladas facilmente por fatores externos e influenciarão e/ou atrapalharão no derradeiro momento do depoimento. Ademais, cediço que este tipo de delito é cometido em sua maioria na clandestinidade e com ausência de outras provas, pois corriqueiramente não deixam vestígios.

Os recorrentes números de casos que chegam ao judiciário contendo o depoimento do ofendido como única prova, geram julgados controversos nos Tribunais, na medida em que alguns magistrados julgam como suficiente a palavra da vítima para prolação de sentença condenatória, enquanto outros entendem carecer de embasamento probatório para criação da certeza e aplicam o in dubio pro reo.

A análise do problema, além de perquirida sob o paradigma de que a condenação, sem a observância de princípios processuais, fere a segurança jurídica do processo, deve ter considerada a gravidade que este delito representa para a sociedade, que o repudia veemente, de todas as maneiras, por envolver vítimas crianças.

Entende-se o temor daqueles que têm de garantir o direito dos infantes em deixar de acreditar em suas palavras, e arriscar livrar um agressor de qualquer punição pelo ato lesivo. Porém, ante ao vasto conteúdo já exposto sobre a fragilidade do depoimento das crianças, o qual é afetado diretamente por emoções, impulsos e temeridade, o julgador tem de se indagar sobre a veracidade das alegações colhidas em depoimento, ainda que uníssonas em diversas ocasiões (tendo em vista que as falsas memórias criam uma certeza inconsciente de sua falsidade) e assim buscar métodos que lhe tragam a certeza. 
Deste modo, imperioso que a aplicação de uma colheita especial de depoimento, como o projeto Depoimento Sem Dano aqui exposto, reduziria os riscos de uma condenação injusta ou até de uma absolvição inadequada, ao passo que a entrevista realizada com a vítima, através de profissionais (psicólogo ou assistente social), visa constatar alegações afetadas por inverdades e ainda protege a criança de um processo de rememoração traumático e com perguntas formuladas, com ou sem intenção, de modo tendencioso à resposta do infante.

\section{REFERÊNCIAS}

ALENCAR, Rosmar Rodrigues; TÁVORA, Nestor. Curso de direito processual penal. 11 ed. Salvador: JusPODIVM, 2009. Disponível em: <https://forumdeconcursos.com/wp-content/uploads/wpforo/ attachments/4032/184-Curso-de-Direito-Processual-Penal-Nestor-Tvora-e-Rosmar-Rodrigues-Alencar-2016.pdf>.

ALVES, Leonardo Barreto Moreira. Processo Penal: parte geral. 8 ed. Bahia: JusPODIVM, 2018. Disponível em: <https://forumdeconcursos. com/wp-content/uploads/wpforo/attachments/2/1948-Coleo-Sinopses-para-Concursos-Processo-Penal-V7-2018-Leonardo-Barreto-Moreira-Alves.pdf>.

ARAÚJO. Caroline. 0 Direito à Prova no Processo Penal. In: GIACOMOLLI, Nereu José. VASCONCELLOS, Vinícius Gomes de. (Orgs.) Processo Penal e Garantias Constitucionais. Rio de Janeiro: Lumen Juris, 2014.

ÁVILA, Gustavo Noronha de. Fraturas do sistema penal: o sintoma das falsas memórias na prova testemunhal. Porto Alegre: PUCRS, 2013.

AZAMBUJA, Maria Regina Fay de. Violência sexual intrafamiliar e produção de prova da materialidade: proteção ou violação de direitos da criança? Porto Alegre: PUCRS, 2010.

BATISTA NEVES, Luiz Gabriel. A FUNÇÃO DO PROCESSO PENAL NO ESTADO DEMOCRÁTICO DE DIREITO. Salvador: UNIFACS, 2014. Disponível em: <www.revistas.unifacs.br/index.php/redu/article/download/2923/2115>.

BRASIL. Constituição Federal de 1988. Disponível em: < http://www. planalto.gov.br/ccivil_03/constituicao/constituicaocompilado.htm>. Acesso em: 08 nov. 2018. 
BRASIL. Decreto-lei no 2.848, de 7 de dezembro de 1940. Código Penal. Diário Oficial [da] República Federativa do Brasil. Poder Executivo. Brasília, DF, 1940. Disponível em: < http://www.planalto.gov.br/ccivil_03/decreto-lei/Del2848compilado.htm>. Acesso em: 08 nov. 2018.

BRASIL. Decreto-lei no 3.689, de 3 de outubro de 1941. Código de Processo Penal. Diário Oficial [da] República Federativa do Brasil. Poder Executivo. Brasília, DF, 1941. Disponível em: < http://www.planalto. gov.br/ccivil_03/Decreto-Lei/Del3689.htm>. Acesso em: 08 nov. 2018.

BRASIL. Decreto-lei no 3.689, de 3 de outubro de 1941. Exposição de Motivos do Código de Processo Penal. Diário Oficial [da] República Federativa do Brasil. Poder Executivo. Brasília, DF, 1941.

CAPEZ, Fernando. Curso de processo penal. 23 ed. São Paulo: Saraiva, 2016. Disponível em: <http://assindelp.org.br/files/conteudo_arquivo/12005/fernando-capez---curso-de-processo-penal---2016.pdf>.

CEZAR, José Antônio Daltoé. Depoimento sem dano: uma alternativa para inquirir crianças e adolescentes nos processos judiciais. Porto Alegre: Livraria do Advogado, 2007.

De CAmargo ARAnha, Adalberto José Q.T. Da Prova No Processo Penal . 5 ed. São Paulo: Saraiva, 1999.

DE OLIVEIRA, Eugênio Pacelli. Curso de processo penal. 18 ed. São Paulo: Atlas, 2014.

DOS REIS, Helena Esser. A Democracia Como Processo: política e educação no pensamento de Tocqueville. [s.l.]: Revista Contexto \& Educação, 2009. v. 24.

FEIX, Leandro da Fonte. Efeito da emoção na memória de crianças. Porto Alegre: PUCRS, 2008.

FISCHER, Douglas. O Sistema acusatório brasileiro à luz da Constituição Federal de 1988 e o PL 156. Salvador: JusPodivm, 2012. Disponível em: <http://www.prrj.mpf.mp.br/custoslegis/revista_2011/2011_Dir_Penal_fischer.pdf $>$.

GIACOMOLLI, Nereu José. 0 devido processo penal: abordagem conforme a Constituição Federal e o Pacto de São José da Costa Rica: cases da Corte Interamericana, do Tribunal Europeu e do STF. São Paulo: Atlas, 2014.

LIMA, Renato Brasileiro de. Manual de processo penal. 4 ed. Salvador: JusPodivm, 2014. Disponível em: < https://forumdeconcursos.com/wp- 
-content/uploads/wpforo/attachments/4032/174-Manual-de-Processo-Penal-Renato-Brasileiro-de-Lima-2016-Volume-Unico-4-Ed.pdf>.

LOFTUS, Elizabeth F. Criando falsas memórias. Revista Scientific American, ano, v. 3, 2004. Disponível em: <http://ateus.net/artigos/ miscelanea/criando-memorias-falsas/>.

LOPES JR, Aury. Você confia na sua memória? Infelizmente, o processo penal depende dela. [s.l.]: CONJUR, 2014.

LOPES JR, Aury. Direito processual penal. 9 ed. São Paulo: Saraiva, 2012.

LOPES JR, Aury. Introdução crítica ao processo penal: fundamentos da instrumentalidade garantista. 3 ed. Rio de Janeiro: Lumen Juris, 2005.

MIRABete, Julio Fabbrini. Processo Penal. 17 ed. São Paulo: Atlas, 2005.

MOREIRA, Rômulo de Andrade. 0 Processo Penal como Instrumento de Democracia. [s.l.]: JUS, abr. 2004. Disponível em: <https://jus.com. br/artigos/5224/o-processo-penal-como-instrumento-de-democracia>.

PISA, Osnilda. Psicologia do testemunho: os riscos na inquirição de crianças. Porto Alegre: PUCRS, 2006.

PRADO, Geraldo. Sistema Acusatório: A Conformidade Constitucional das Leis Processuais Penais. Rio de Janeiro: Lumen Juris, 2005. Disponível em: <http://professor.pucgoias.edu.br/SiteDocente/admin/ arquivosUpload/7782/material/Livro\%20-Sistema\%20Acusatorio\%20-\%20Geraldo\%20Prado.pdf>.

SANTOS, Benedito Rodrigues dos; GONÇALVES, Itamar Batista (Ed.). Depoimento sem medo (?): culturas e práticas não-revitimizantes: uma cartografia das experiências de tomada de depoimento especial de crianças e adolescentes. [s.l.]: Childhood Brasil (Instituto WCF-Brasil), 2009.

SIQUEIRA, Dirceu Pereira; DE ÁVILA, Gustavo Noronha. Acesso à justiça e os direitos da personalidade: elementos para a formação da prova testemunhal no novo código de processo penal, levando a psicologia do testemunho à sério!. Canoas: Revista Eletrônica Direito e Sociedade-REDES, 2018. v. 6. Disponível em: <https://www. academia.edu/36742736/Elementos_para_a_Forma\%C3\%A7\%C3\%A3o_ da_Prova_Testemunhal_no_Novo_C\%C3\%B3digo_de_Processo_ Penal_2018_?auto=download>. 
STEIN, Lilian M. Falsas memórias: Fundamentos científicos e suas aplicações clínicas e jurídicas. Porto Alegre: Artmed, 2010. p. 165.

THUMS, Gilberto. Sistemas Processuais Penais. Rio de Janeiro: Lumen Juris, 2006.

TOURinho FIlho, Fernando da Costa. Processo penal. 26 ed. São Paulo: Saraiva, 2004.

VOLPATO, Dayana. A gestão da prova como elemento determinante do sistema processual penal. Itajaí: UNIVALI, 2010. Disponível em: <http://siaibib01.univali.br/pdf/Dayana\%20Volpato.pdf>. 